\title{
СОЦАЛЬНО-ЕКОНОМІЧНІ ТА ПОЛІТИЧНІ ПЕРЕДУМОВИ КОНСТРУЮВАННЯ ПЕРШОЇ НАВЧАЛЬНОЇ ПРОГРАМИ 3 ФІЗИЧНОЇ КУЛЬТУРИ В НЕЗАЛЕЖНІЙ УКРАЇНІ
}

\author{
Інна Омельяненко ${ }^{1}$ \\ ${ }^{1}$ Тернопільський національний педагогічний університет імені Володимира Гнатюка, Тернопіль, Україна, \\ omelinna23@gmail.com \\ https://doi.org/10.29038/2220-7481-2020-03-10-16
}

\begin{abstract}
Анотаціï
Aктуальність. Упродовж незалежності України ії шкільна система освіти перебуває в зоні неперервних змін: реформ, модернізацій, трансформацій, оновлення, магістральним напрямом яких $€$ побудова національної гуманної, демократичної, особистісно орієнтованої школи. Серед ії нерозв'язаних проблем - недосконалість змісту загальної середньої освіти, який є основною складовою частиною освітньої системи. Зміст освіти в узагальненій формі відображає досягнутий суспільством рівень культури для подальшого його піднесення. Фізичне виховання як одна з форм соціальних відносин $€$ продуктом діючої суспільно-економічної формації. Тому функціонування системи фізичного виховання та іiі зміни зумовлені соціально-культурними, політичнорелігійними, економічними й особистісними факторами. Їх дослідження дасть змогу усвідомити закономірності розвитку системи фізичного виховання України; сприятиме виробленню науково обгрунтованого курсу ії подальшого поступу; запобігатиме суб’єктивним рішенням; формуватиме національну самосвідомість як умову збереження незалежності України. Мета дослідження - виявити політичні, економічні та суспільні передумови розробки навчальної програми з фізичної культури для загальноосвітніх шкіл (1993р.) Методи дослідження - вивчення та узагальнення інформаційних джерел, порівняльного аналізу, причинно-наслідкового аналізу, герменевтичний. Результати дослідження. Розробка першої навчальної програми з фізичної культури в незалежній Україні (1993), уведена в практику загальноосвітніх закладів освіти невдовзі після проголошення іï самостійності, дублювала свою попередницю УРСР (1988) в основних положеннях пояснювальної записки, попри несуттєві розбіжності. Інерційне «відлуння» радянської системи в прийнятому документі зумовлене низкою об'єктивних політичних, економічних та суспільних обставин: проголошенням незалежності України в 1991 р.; недостатнім часом для усвідомлення чиновниками свого місця в процесі державотворення й масштабу нових завдань; домінуванням бюрократичних методів управління та неготовністю фахівців до прояву самостійності в прийнятті оригінальних рішень; відсутність економічних перетворень, бідністю й соціальною незахищеністю українців; відголосом ієрархії культурних цінностей радянських часів.
\end{abstract}

Ключові слова: навчальна програма, фізичне виховання, незалежність України, суспільні відносини, економічні перетворення.

Инна Омельяненко. Социально-экономические и политические предпосылки конструирования первой учебной программы по физической культуре в независимой Украине. Актуальность. За время независимости Украины ее школьная система образования находится в зоне непрерывных изменений: реформ, модернизаций, трансформаций, обновления, магистральным направлением которых является построение национальной гуманной, демократической, личностно ориентированной школы. Среди ее нерешенных проблем - несовершенство содержания общего среднего образования, которое является основной составляющей образовательной системы. Содержание образования является основной составляющей образовательной системы, которая в обобщенной форме отражает достигнутый обществом уровень культуры для дальнейшего его развития. Физическое воспитание как одна из форм социальных отношений является продуктом действующей общественно-экономической формации. Поэтому функционирование системы физического воспитания и ее изменения обусловлены социально-культурными, политико-религиозными, экономическими и личностными факторами. Их исследование позволит осознать закономерности развития системы физического воспитания Украины; будет способствовать выработке научно обоснованного курса ее дальнейшего продвижения; предотвращать субъективные решения, формировать национальное самосознание как условие сохранения независимости Украины. Цель исследования - выявить политические, экономические и общественные предпосылки разработки учебной программы по физической культуре для общеобразовательных школ (1993). Методы исследования - изучение и обобщение информационных источников, сравнительного анализа, причинно-следственного анализа, герменевтический. Результаты исследования. Разработка первой учебной программы по физической культуре в независимой Украине (1993), введена в практику общеобразовательных учебных заведений вскоре после провозглашения в ней самостоятельности, дублировала свою предшественницу УССР (1988) в основных положениях пояснительной записки, несмотря на несущественные разногласия.

10 ISSN 2410-2156 (Online), ISSN 2220-7481 (Print)

(C) 2020 Східноєвропейський національний університет імені Лесі Українки. Ця стаття відкритого доступу на умовах CC BY-NC 4.0 
Инерционное «эхо» советской системы в принятом документе обусловлено рядом объективных политических, экономических и общественных обстоятельств: провозглашением независимости Украины в 1991 г.; недостаточным временем для осознания чиновниками своего места в процессе создания государства и масштаба новых задач; доминированием бюрократических методов управления и неготовностью специалистов к проявлению самостоятельности в принятии оригинальных решений; отсутствием экономических преобразований, бедностью и социальной незащищенностью украинцев; отзвуком иерархии культурных ценностей советских времен.

Ключевые слова: учебная программа, физическое воспитание, независимость Украины, общественные отношения, экономические преобразования.

Inna Omelianenko. Social, Economic, and Political Preconditions of the First Physical Culture Curriculum Construction in Independent Ukraine. Research Relevance. During the Ukraine independence, its school system of education lies in the zone of continuous change: reforms, modernizations, transformations, renewals, the fundamental direction of which is to build national humane, democratic, and personality-oriented school. Among its unresolved issues is the imperfection of the content of general secondary education, which is a primary component of the educational system. The content of education in the generalized form reflects the level of culture achieved by society for its further promotion. Physical education, as one of the forms of social relations, is a product of active social and economic formation. Therefore, the physical education system functioning and its changes are conditioned by social and cultural, political and religious, economic and personality factors. Their studying will help to comprehend the regularities of the development of the physical education system in Ukraine; will contribute to the creation of scientifically grounded direction of its further progress; will prevent subjective decisions; will form national selfconsciousness as the condition for preserving Ukraine's independence. The Research Aimed to identify the political, economic and social preconditions for the development of the physical education curriculum for secondary schools (1993). Research Methods include study and generalization of information resources, comparative analysis, causal analysis, hermeneutic method. Research Results. The development of the first curriculum in physical education in independent Ukraine (1993) introduced into the practice of secondary schools shortly after the proclamation of its independence, duplicated its predecessor in the USSR (1988) in the main provisions of the explanatory note despite minor differences. The inertial «echo» of the Soviet system in the adopted document is preconditioned by a number of objective political, economic, and social circumstances: the declaration of Ukraine independence in 1991; insufficient time for officials to realize their place in the process of state formation and the scale of new tasks; the dominance of bureaucratic management methods and the unreadiness of specialists to demonstrate independence in making original decisions; the lack of economical transformations, poverty and social insecurity of Ukrainians; the echo of the hierarchy of cultural values of Soviet times.

Key words: curriculum, physical education, independence of Ukraine, social relations, economic transformations.

Актуальність проблеми. Визначення навчальної програми в галузі фізичного виховання потребує стандартизації, що сприятиме впорядкуванню переліку функцій, ії видів, які сьогодні порізному тлумачаться науковцями [10]. Утім, більшість із них (Свирська Т., Болюбаш Я., Лопуга Е., Шиян Б., Омельяненко I, Круцевич Т. та інші) стверджують, що цей документ визначає зміст освіти. Зміст є основною складовою частиною освітньої системи. У ньому в узагальненій формі відображено досягнутий суспільством рівень культури, соціальний досвід, який передається наступному поколінню для збереження й подальшого розвитку [7; 13].

Кожний етап суспільного буття визначається характерним для нього змістом освіти, зумовленим розвитком соціально-економічних відносин, тенденціями суспільного розвитку та завданнями суспільства й держави в галузях політики, економіки та виховання, які формують соціальне замовлення для системи освіти; досягненнями науки, виробництва й техніки; значенням окремих галузей науки в загальній системі людських знань; специфіки системи освіти країни [5; 6]. Поруч 3 об'єктивними зміст освіти детермінований і суб’єктивними чинниками: політикою панівних сил суспільства, методологічною позицією провідних учених, педагогічним досвідом тощо [9].

Фізичне виховання зароджувалось у надрах суспільства і є продуктом тієї суспільної формації, у якій воно існує. Фізичне виховання як одна зі сфер прояву суспільних відносин тісно пов'язане із соціально-економічними системами суспільства: економікою, політикою, наукою та культурою. Структура, ідеали, принципи, ціннісні орієнтири, функції й зміст фізичної культури визначаються потребами та конкретними формами суспільної організації людей на певних етапах історичного розвитку. Це означає, що формування, функціонування системи фізичної культури і іiі зміни зумовлені соціально-культурними, політично-релігійними, економічними та особистісними факторами $[1 ; 8]$. Їх дослідження дасть змогу усвідомити закономірності розвитку системи фізичного виховання України; сприятиме виробленню науково обгрунтованого курсу іï подальшого поступу; запобігатиме 
суб'єктивним рішенням; формуватиме національну самосвідомість як умову збереження незалежності України.

Мета дослідження - виявити політичні, економічні та суспільні передумови розробки навчальної програми з фізичної культури для загальноосвітніх шкіл (1993р.).

Методи дослідження. Для досягнення мети використано теоретичні методи дослідження. Вивчення та узагальнення інформаційних джерел для з'ясування сутності й значення змісту освіти та факторів, які його визначають; політичних подій, особливостей економічного й соціального розвитку в Україні в першій половині 90-х років минулого століття.

Метод порівняльного аналізу, який використовували для зіставлення змісту навчальних програм (1988 та 1993 рр.) і виявлення спільного та різного в їхньому змісті.

Метод причинно-наслідкового аналізу, котрий застосовували для визначення ймовірних причин, що зумовили розробку навчальної програми з фізичної культури для загальноосвітніх навчальних закладів (1993 р.).

Герменевтичний метод, який використовували для історичного тлумачення та ретроспективної інтерпретації змісту навчальної програми з фізичної культури для загальноосвітніх навчальних закладів (1993 p).

Результати дослідження. Першим документом у незалежній Україні, що визначав зміст та організаційно-методичні особливості фізичного виховання в загальноосвітній школі, стали «Комплексні програми середньої загальноосвітньої школи з фізичної культури для 1-11 класів», 1993 [4]. Ї̈ї випуск зумовлений ухваленням позачерговою сесією Верховної Ради УРСР акта проголошення незалежності України в 1991 р. Ця подія стала точкою відліку самостійної Української держави та нового етапу історії України. Проголошення незалежності стало початком перехідному періоду розростання незалежної країни. Його сутність передбачала перехід України на якісно вищий рівень суспільного розвитку: у політичній сфері - від тоталітаризму до демократії, в економічній - від командної до ринкової економіки, у гуманітарній - від класових до загальнолюдських цінностей, у міжнародній - від об'єкта до суб'єкта геополітики, а в цілому - перехід від становища «уламка імперії» до власної державності, від формальної незалежності - до реального суверенітету [2].

Натомість українське суспільство було недостатньо підготовлене до державотворчого процесу. Перетворення в Україні почалися за вкрай низького рівня політичної та економічної культури мислення. Рішуча відмова від існуючого до серпня 1991 р. зразка суспільного розвитку в умовах відсутності науково обгрунтованої моделі побудови незалежної держави зумовила втрату орієнтирів, розгубленість. I, як наслідок - «тупцювання» на роздоріжжі реформ в усіх сферах життєдіяльності країни.

Зміст першої в незалежній Україні комплексної програми середньої загальноосвітньої школи 3 фізичної культури для 1-11 класів є яскравим підтвердженням «пробуксовки» реформ в освіті. Порівняння пояснювальних записок до останньої навчальної програми з фізичної культури в УРСР (1988 р.) [3] та першої - у незалежній Україні (1993 р) [4] виявило домінуючу ідентичність їх змісту. Тотожність документів закладено вже в назвах, які вказують на комплексний характер навчальних програм. Дублювання структури навчальної програми, завдань й організаційно-методичних положень іiі реалізації демонструють відсутність державної освітньої парадигми в перші роки незалежної України. Така тактика у визначенні змісту шкільного фізичного виховання зумовлена низкою об'єктивних причин:

- по-перше, на час проголошення Україною незалежності в суспільній свідомості не встигло сформуватися й закріпитись усвідомлення масштабу нових завдань, а більшість чиновників чітко не визначили свого місця в процесі державотворення. Підтвердження такого припущення - перелік завдань фізичного виховання, маніфестованих навчальною програмою 1993 р. У такому самому формулюванні завдання фізичного виховання школярів подаються в навчальній програмі УРСР (1988). Вони - кліше, характерне для навчальних програм радянського періоду та орієнтують фахівця на «...збереження і зміцнення здоров'я школярів, виховання загальнолюдських моральних цінностей та потреби у систематичних заняттях, набуття знань у галузі гігієни, медицини, фізичної культури та життєво важливих рухових умінь і розвиток фізичних якостей». У цих положеннях відсутній дух демократії з орієнтацією на педагогіку партнерства, дитиноцентризм, демократичні компетентності, розвиток здібностей учнів, творчої особистості, національну ідентифікацію;

- по-друге, високий рівень інтегрованості України до союзного господарського комплексу не сприяв економічним перетворенням в Україні, формуванню ринкового середовища, зберігав 
бюрократичні методи управління, свідчив про відсутність послідовної програми господарської реформи з відповідною заскорублістю, інертністю та імітацією змін у різних галузях народного господарства України, освіти й фізичного виховання;

- по-третє, розвал системи, діяльність якої підпорядковувалася не законам, а постановам ЦК КПРС з ідеологічними штампами про переваги соціалізму, з одного боку, безумовно, розкріпачив розвиток фізичної культури та спорту в нашій країні й розвіяв міф про масовий фізкультурний рух із «дутими» цифрами. Проте, з іншого боку, висунув серйозні проблеми перед фахівцями, не готовими до прояву самостійності в прийнятті відповідальних, оригінальних рішень щодо реформування фізичної культури в освіті;

- по-четверте, у перші місяці розпаду Радянського Союзу в Україні зроблено кроки в напрямі ринкових перетворень. Так, у березні 1992 р. Верховною Радою України прийнято постанову «Про основи національної економічної політики України», якою передбачено роздержавлення й приватизацію, структурну перебудову та модернізацію промисловості [12]. Програма ринкових перетворень отримала схвалення МВФ. Утім, документи прийняті Верховною Радою України, постанови й рішення урядів не принесли очікуваних результатів. Лібералізація цін в умовах відсутності конкуренції та панування командно-адміністративної системи управління економікою Україна призвели до глибокої економічної кризи й вибухового зростання цін у 20 разів із рівнем інфляції 200 \% (найвідчутніших утрат українська економіка зазнала в 1990-1994рр.). Спеціалісти Світового банку прийшли до висновку: у третини населення України загальний рівень споживання продуктів майже на $10 \%$ нижчий від рівня фізичного виживання [11].

Бідність і соціальна незахищеність українців переорієнтували вектори розвитку країни, спрямовані на модернізацію й реформи, у тому числі в гуманітарній сфері, на пріоритети виживання 3 характерними для нього безініціативністю та відсутністю творчого підходу до розв'язання проблем освіти загалом і фізичного виховання зокрема, що доцільно розглядати як одну з об'єктивних причин запозичення навчальної програми з пострадянських часів.

До того ж ситуація ускладнювалася тим, що в централізованому СРСР домінувала «радянська культура», натомість українське часто самі українці сприймали як провінційне, другорядне. Така ієрархія культурних цінностей вкарбувалася в масову свідомість мільйонів. Підтвердження цього відсутність у першій навчальній програмі незалежної України положень, які б свідчили про поступ у національній політиці, спрямованість на розвиток національної культури й патріотичне виховання підростаючого покоління в умовах самостійної держави. У пояснювальній записці до документа лише зазначено про те, що «на уроках слід використовувати рухливі народні ігри», що є тотожним вислову в останній навчальній програмі УРСР. Попри це, в останньому документі використано менш прогресивну дефініцію для демократичного суспільства - «національні рухливі ігри».

Вимушені перефразування окремих положень у документі 1993 р. на кшталт «готовності до праці й захисту Української державності» проти «готовності до праці та захисту Вітчизни» у програмі 1998 р.; вилучення фраз, які втратили свою актуальність в умовах самостійної держави, наприклад про комплекс ГПО СРСР; чи то посилань на нормативні документи (рекомендації Міністерством освіти України, 1992 р. проти затверджених Міністерством освіти СРСР); уключення шаблонної методичної інформації, наприклад про вимоги до уроку (диференційований підхід, досягнення високої моторної щільності, формування навичок й умінь самостійно займатися фізичною культурою); незначне переформатування структури програми з вилученням розділу про професійноприкладну фізичну підготовку не змінили дух нового документа. Інерційна модель «відлуння» радянської системи логічно вписувалася в авторитарний політичний контекст української модернізації в перші роки становлення державності.

Ситуація в народному господарстві характеризувалася деформованою структурою виробництва зі значною мірою мілітаризації [11]. Така характеристика виробництва молодої держави відображена й у галузі фізичного виховання. Так, пояснювальною запискою до навчальної програми 3 фізичної культури передбачено «...досягнення готовності юнаків до служби в Збройних силах України». Для цього «...першорядного значення набуває розвиток у них сили, витривалості, швидкості, спритності, а також сміливості й стійкості до несприятливого впливу зовнішнього середовища». Тому документ закликав створювати в школах усі умови для того, щоб кожен старшокласник міг самостійно готуватися до виконання навчальних нормативів, систематично займався військово-прикладними видами спорту, постійно турбувався про своє фізичне вдосконалення, виховував у собі мужність, силу волі, готовність отримувати великі фізичні навантаження, умів надавати першу медичну 
допомогу й проводити заняття з товаришами. Відповідно, однією з вимог до учнів, які закінчили загальноосвітню школу III ступеня, стало володіння юнаками військово-прикладними навичками. Таке формулювання завдання та вимог фізичного виховання до випускників загальноосвітніх закладів цілком відповідало духу мілітариської країни, яка лише взяла курс на військову конверсію.

Дискусія. Від часу проголошення Україною незалежності фахівці в галузі фізичного виховання регулярно зверталися до історичних основ програмотворення для загальноосвітніх закладів. Ними досліджувався поступ програмових основ фізичного виховання школярів шляхом компаративного аналізу чинної в конкретний історичний період навчальної програми та ії попередниці. Предметом вивчення науковців були дидактичний зміст документів й організаційно-методичні особливості його реалізації, передбачені пояснювальною запискою. Так, В. Новак (2001), досліджував проблеми першої навчальної програми 3 фізичної культури в незалежній Україні. А. Гаркавенко (2000), О. Андреєва (2001), І. Бакіко (2007), Т. Круцевич (2008), Ю. Васьков (2009), О. Шиян, Н. Сороколіт, I. Турчик (2013), Н. Бєлікова, Г. Гац, С. Козібродський, А. Цьось (2015) виявили системні недоліки навчальних програм із фізичної культури для загальноосвітніх навчальних закладів, уключаючи документ 1993 р. Окремі фахівці (Т. Диба, М. С. Косік, Н. Косік (2012); В. Ворона (2010); М. Оліяр (2019)) у процесі наскрізного аналізу навчальних програм з фізичної культури в незалежній Україні торкалися лише окремих їх розділів (модулів). В. Білецька (2008), М. Стефанишин (2017) висловили критичні міркування щодо систем оцінювання досягнень школярів у процесі фізичного виховання. Утім, попри ствердження провідних освітян (В. Кремінь (2016) і фахівців із фізичної культури про соціально-економічну обумовленість програмових основ фізичного виховання (I. Бакіко (2007), Т. Круцевич (2015)), результати наукових пошуків фахівців не показують передумови прогресивних, регресивних змін чи відсутності будь-яких новацій у процесі розробки та імплементації кожної наступної навчальної програми з фізичної культури для школярів.

Експлікація загального положення про соціально-економічну обумовленість програмових основ фізичного виховання шляхом зіставлення конкретних історичних, політичних подій, особливостей соціального розвитку України в перші роки незалежності й змісту навчальної програми з фізичної культури 1993 р. дає змогу сприймати ії̈ недоліки як об'єктивну реальність. Авторська інтерпретація соціально-економічних і політичних передумов першої навчальної програми з фізичної культури в незалежній Україні та наукове тлумачення історичних обставин набуття нею чинності $є$ прецедентом для наступних наукових дискусій про причини якісних змін у програмотворенні з фізичної культури школярів, а також основою для виявлення інших історичних фактів і передумов, у тому числі культурних та особистісних, нормативно-правових і медико-демографічних, що визначали зміст навчальної програми з фізичної культури 1993 р. й інших навчальних програм, чинних у різні роки в незалежній Україні. Їх узагальнення створить загальну цивілізаційну картину розвитку програмотворення в Україні для усвідомлення історичних передумов, які треба враховувати, тих обставин, які можна та потрібно міняти вже сьогодні, і таких, які передбачувано зміняться в результаті обраного країною напряму розвитку для випереджувального розвитку нормативних приписів у наступних навчальних програмах із фізичної культури.

Висновки. Перша навчальна програма з фізичної культури в незалежній Україні (1993), уведена в практику загальноосвітніх закладів освіти невдовзі після проголошення iï самостійності (1991), дублювала свою попередницю УРСР (1988) в основних положеннях пояснювальної записки, попри несуттєві розбіжності. Інерційне «відлуння» радянської системи в прийнятому документі зумовлено низкою об'єктивних обставин: у суспільній свідомості не встигло сформуватися й закріпитися усвідомлення масштабу нових завдань, а більшість чиновників чітко не визначило свого місця в процесі державотворення; високий рівень інтегрованості України до союзно-господарського комплексу зберігало бюрократичні методи управління; неготовність фахівців до прояву самостійності в прийнятті відповідальних, оригінальних рішень щодо реформування фізичної культури в освіті; відсутність економічних перетворень, бідність і соціальна незахищеність українців переорієнтували вектори розвитку країни, спрямовані на модернізацію й реформи, у тому числі в гуманітарній сфері, на пріоритети виживання 3 характерними для нього безініціативністю та відсутністю творчого підходу до розв'язання проблем освіти; відголос ієрархії культурних цінностей радянських часів зі сприйняттям українського часто самими українцями як провінційного й другорядного.

Перспективи подальших досліджень. Подальшими дослідженнями передбачено виявлення соціально-економічних і політичних передумов конструювання навчальної програм із фізичної культури 1998 р. 


\section{Джерела та література}

1. Довгич Н. Соціалізаційний зміст фізичної культури у контексті національно-культурної специфіки. Олімпійський спорт і спорт для всіх: тези доп. IX Міжнар. наук. конгресу. Київ: Олімп. літ., 2005. C. 58.

2. Ігнатенко М. Висвітлення соціально-економічного розвитку українського села у 1990-2000 pp. у сучасній науковій літературі. Вісник Академії праці та соціальних відносин Федерацї профспілок України. 2009. № 5. C. 108-113.

3. Комплексна програма фізичного виховання учнів 1-11 класів загальноосвітньої школи/Розроблена Науково-дослідним інститутом фізіології дітей та підлітків Академії педагогічних наук СРСР і відділом фізичного виховання Мін. освіти СРСР; відп. за вип. зав. лабораторією фізичного виховання Республіканського учб.-метод. кабінету Мін. освіти УРСР Леонов О. З. Київ: Рад. шк., 1988. С. 59.

4. Комплексні програми середньої загальноосвітньої школи з фізичної культури для 1-11 класів/відп. за вип. провідний інспектор відд. організац.-пед. роботи Упр. шкіл Мін. освіти України П. С. Срьоменко. Київ: Освіта. 1993. С. 52.

5. Корсакова О., Трубачова С. Зміст сучасної шкільної освіти: дидактичний аспект. Відкритий урок: розробки, технології, досвід. 2006. № 3-4. С. 3-11.

6. Корсакова О. Дидактичні підходи до оновлення змісту освіти. Відкритий урок: розробки, технології, досвід. 2006. № 5-6. С. 3-15.

7. Круцевич Т. Теорія і методика фізичного виховання: підруч. для студентів вищ. навч. закл. фіз. вих. $\mathrm{i}$ спорту: у 2-х Т. Т1: Загальні основи теорії і методики фізичного виховання. Київ: Олімп. літ., 2008. C. 29.

8. Кун Л. Всеобщая история физической культуры и спорта. Москва: Радуга, 1982.

9. Левченко А. В. Спорт и политика. Взаимосвязь двух факторов на рубеже двух историй - во времена СССР и в современной, независимой Украине. Олімпійський спорт і сnорт для всіх: тези доп. IX Міжнар. наук. конгресу. Київ: Олімп. літ., 2005. С. 70.

10. Омельяненко I. О. Про проблему поняття навчальної програми з фізичної культури. Вісник Чернігівського національного педагогічного університету імені Т. Г. Шевченка: Серія: Педагогічні науки. Фізичне виховання та спорт. Чернігів: ЧНПУ, 2014. Вип. 118. Т. 2. С. 165-169.

11. Офіцинський Р. Сучасні оцінки внутрішнього розвитку України 1990-х рр. Науковий вісник Ужггородського національного університету. Серія: Історія. Ужгород, 2002. Вип. 7. С. 179-185.

12. Постанова Верховної Ради України «Про основи національної економічної політики України» N 2226 XII від 24 березня 1992 року. URL: http://zakon2.rada.gov.ua/laws/show/2226-12

13. Шиян Б., Омельяненко І. Теорія і методика фізичного виховання школярів: навч. посіб.: в 2 ч. Ч. 2. Тернопіль: Навч. кн.-Богдан, 2012. С. 200.

\section{References}

1. Dovgy`ch, N. (2005). Socializacijny`j zmist fizy`chnoyi kul`tury`u konteksti nacional’no-kul`turnoyi specy`fiky`. Olimpijs`ky`j sport i sport dlya vsix: tezy` dopovidej IX Mizhnarodnogo naukovogo kongresu, 58.

2. Ignatenko, M. (2009). Vy`svitlennya social`no-ekonomichnogo rozvy`tku ukrayins`kogo sela u 1990-2000 rr. u suchasnij naukovij literaturi. Visny`k Akademiyi praci ta social`ny`x vidnosy`n Federaciyi profspilok Ukrayiny, 5, 108-113.

3. Kompleksna programa fizy`chnogo vy`xovannya uchniv 1-11 klasiv zagal`noosvitn`oyi shkoly (1988). Rozroblena Naukovo-doslidny`m insty`tutom fiziologiyi ditej ta pidlitkiv Akademiyi pedagogichny`x nauk SRSR i viddilom fizy`chnogo vy`xovannya Ministerstva osvity`SRSR. Vidpovidal`ny`j za vy`pusk zav. laboratoriyeyu fizy`chnogo vy`xovannya Respublikans`kogo uchbovo-metody`chnogo kabinetu Ministerstva osvity`URSR Leonov O. Z., 60.

4. Kompleksni programy`seredn`oyi zagal`noosvitn`oyi shkoly`z fizy`chnoyi kul tury` dlya 1-11 klasiv (1993). Vidpovidal`ny`j za vy`pusk providny`j inspektor viddilu organizacijno-pedagogichnoyi roboty`Upravlinnya shkil Ministerstva osvity`Ukrayiny`P. S. Yer`omenko.

5. Korsakova, O. Trubachova, S. (2006). Zmist suchasnoyi shkil`noyi osvity` dy`dakty`chny`j aspekt. Vidkry`ty`j urok: rozrobky`, texnologiyi, dosvid, 3-4, 3-11.

6. Korsakova, O. (2006). Dy`dakty`chni pidxody` do onovlennya zmistu osvity`. Vidkry`ty`j urok: rozrobky`, texnologiyi, dosvid, 5-6, 3-15.

7. Krucevy`ch, T. (2008). Teoriya i metody`ka fizy`chnogo vy`xovannya: pidruchny`k dlya studentiv vy`shhy`x navch. zakladiv fiz. vy`xovannya i sportu: u 2-x T. T1: Zagal`ni osnovy` teoriyi i metody`ky` fizy`chnogo vy`xovannya. Ky`yiv Oly`mpy`jskaya ly`teratura, 29.

8. Kun, L. (1982).Vseobshhaya y`story`ya fy`zy`cheskoj kul`turы y`sporta. Moskva: Raduga.

9. Levchenko, A. V. (2005). Sport y` poly`ty`ka. Vzay`mosvyaz`dvux faktorov na rubezhe dvux y`story`j - vo vremena SSSR y`v sovremennoj, nezavy`sy`moj Ukray`ne.. Olimpijs`ky`j sport i sport dlya vsix: tezy` dopovidej IX Mizhnar. nauk. kongresu. Ky`yiv: Olimp. lit., 70. 
10. Omel yanenko, I. O. (2014). Pro problemu ponyattya navchal`noyi programy`z fizy`chnoyi kul`tury`. Visny`k Chernigivs `kogo nacional `nogo pedagogichnogo universy`tetu imeni T. G. Shevchenka: Seriya: Pedagogichni nauky`. Fizy`chne vy`xovannya ta sport. Chernigiv: ChNPU, 118(2), 165-169.

11. Oficy`ns`ky`j, R. (2002). Suchasni ocinky` vnutrishn`ogo rozvy`tku Ukrayiny`1990-x rr. Naukovy`j visny`k Uzhgorods`kogo nacional `nogo universy`tetu. Seriya: Istoriya. Uzhgorod, 7, 179-185.

12. Postanova Verxovnoyi Rady`Ukrayiny` «Pro osnovy`nacional noyi ekonomichnoyi polity`ky`Ukrayiny`» N 2226-XII vid 24 bereznya 1992 roku. Refrieved from: http://zakon2.rada.gov.ua/laws/show/2226-12.3

13. Shy`yan, B., Omel yanenko, I. (2012). Teoriya i metody`ka fizy`chnogo vy`xovannya shkolyariv: navch. posib. v 2 ch. Ch. 2. Ternopil’:Navchal`na kny`ga - Bogdan, 200.

Стаття надійшла до редакції 30.06.2020 p. 